\title{
Improvement in melting and baking properties of low-fat Mozzarella cheese
}

\author{
R. Wadhwani, W. R. McManus, and D. J. McMahon ${ }^{1}$ \\ Department of Nutrition, Dietetics, and Food Sciences Western Dairy Center, Utah State University, Logan 84322-8700
}

\begin{abstract}
Low-fat cheeses dehydrate too quickly when baked in a forced air convection oven, preventing proper melting on a pizza. To overcome this problem, low-fat Mozzarella cheese was developed in which fat is released onto the cheese surface during baking to prevent excessive dehydration. Low-fat Mozzarella cheese curd was made with target fat contents of $15,30,45$, and $60 \mathrm{~g} / \mathrm{kg}$ using direct acidification of the milk to $\mathrm{pH} 5.9$ before renneting. The 4 portions of cheese curd were comminuted and then mixed with sufficient glucono- $\delta$-lactone and melted butter $(45,30,15$, or $0 \mathrm{~g} / \mathrm{kg}$, respectively), then pressed into blocks to produce low-fat Mozzarella cheese with about $6 \%$ fat and $\mathrm{pH} 5.2$. The cheeses were analyzed after $15,30,60$, and $120 \mathrm{~d}$ of storage at $5^{\circ} \mathrm{C}$ for melting characteristics, texture, free oil content, dehydration performance, and stretch when baked on a pizza at $250^{\circ} \mathrm{C}$ for $6 \mathrm{~min}$ in a convection oven. Cheeses made with added butter had higher stretchability compared with the control cheese. Melting characteristics also improved in contrast to the control cheese, which remained in the form of shreds during baking and lacked proper melting. The cheeses made with added butter had higher free oil content, which correlated $\left(\mathrm{R}^{2}\right.$ $\geq 0.92$ ) to the amount of butterfat added, and less hardness and gumminess compared with the control low fat cheese.
\end{abstract}

Key words: Mozzarella, melting, stretchability, free oil

\section{INTRODUCTION}

Proper melting of cheese is an essential attribute of Mozzarella cheese for its functional performance on a baked pizza. This is influenced by fat content (Merrill et al., 1994; Paulson et al., 1998), moisture content (Perry et al., 1997), combined fat and moisture content (Barz and Cremer, 1993), sodium content (Paulson et al., 1998), total calcium content (Paulson et al., 1998; McMahon and Oberg, 2000; Joshi et al., 2003a,b), protein-bound calcium (Walstra and Jenness, 1984),

Received October 21, 2010.

Accepted December 31, 2010.

${ }^{1}$ Corresponding author: donald.mcmahon@usu.edu extent and type of proteolysis (Oommen et al., 2002), and the conditions of baking. An increased meltability of 2.6 times was reported with the decrease of calcium level from 0.65 to $0.35 \%$ (Joshi et al., 2004). Such low levels of calcium are obtained when Mozzarella cheese is made using direct acidification (McMahon et al., 2005). Decreasing the calcium causes an increased interaction of proteins with surrounding serum, causing more hydration of proteins and better melting of the cheese.

In many commercial pizza operations (especially quick-serve restaurants), a forced-air convection oven is used for baking. These ovens employ higher temperatures $\left(250\right.$ to $300^{\circ} \mathrm{C}$ ) and shorter times (4 to $6 \mathrm{~min}$ ) compared with a home oven or other nonconvection oven. With heating using convection ovens, the movement of hot air against the pizza surface results in considerable loss of moisture from the pizza ingredients (i. e., dough forming the crust, cheese, and other toppings). During baking, low-moisture part skim Mozzarella cheese and low-fat Mozzarella cheese can lose up to approximately $28 \mathrm{~g} / 100 \mathrm{~g}$ (Rudan and Barbano, 1998), with a resultant moisture content loss of up to $50 \%$. One way of controlling melting and browning characteristics of low-fat Mozzarella cheese is to prevent surface drying during baking by spraying the cheese with a thin film of vegetable oil (Rudan and Barbano, 1998; Zaikos et al., 1999).

Excessive surface drying of cheeses made with low butterfat contents can also be retarded by increasing the water-holding capacity of the cheese protein matrix. McMahon and Oberg (2000) used direct acidification for making a nonfat Mozzarella cheese in which more calcium is lost during cheesemaking, resulting in a more hydrated protein matrix (Paulson et al., 1998; Guinee et al., 2002). Such directly acidified cheeses typically have higher moisture levels, calcium-to-protein ratios that are $30 \%$ lower, and increased melting properties compared with culture-acidified cheeses (Sheehan and Guinee, 2004). Metzger et al. (2001) reported that water-insoluble calcium and proteolysis were associated with changes in the post-melt chewiness of low-fat Mozzarella cheese. At $\mathrm{pH}>5.0$, calcium content controls cheese functionality, whereas at $\mathrm{pH}<5.0, \mathrm{pH}$ has a greater influence on texture and melting (McMahon et al., 2005). 
The aim of our research was to determine if fat could be added internally to cheese and provide a source of more freely expressible oil during pizza baking. To do this, cheese curd with target fat contents of 15, 30, 45 , and $60 \mathrm{~g} / \mathrm{kg}$ were made using direct acidification, comminuted, mixed with additional butterfat, and pressed to produce low-fat Mozzarella cheese containing $6 \%$ (wt/wt) fat. Melting and baking properties of the cheeses were examined along with an examination of cheese microstructure to determine the location of added butter within the low-fat cheese matrix.

\section{MATERIALS AND METHODS}

\section{Cheese Making}

Fresh milk was obtained from the George B. Caine Dairy Research and Teaching Center (Wellsville, UT) and then transported to the Gary H. Richardson Dairy Products Laboratory, where the milk was standardized to casein-fat ratios of $20,15,7$, and 5 and pasteurized at $73^{\circ} \mathrm{C}$ for $15 \mathrm{~s}$. Each $136-\mathrm{kg}$ batch of milk was cooled and then acidified with vinegar (Sysco Corp, Houston, $\mathrm{TX}$ ) to $\mathrm{pH} 5.9$, heated to $32^{\circ} \mathrm{C}$, and then renneted. Double-strength chymosin (ChyMax, Chr. Hansen, Inc., Milwaukee, WI) was diluted 20-fold with chlorine-free cold water, added to milk, stirred, and let stand for 20 min. Curd was cut when firm with 1-cm wire knives, healed for $5 \mathrm{~min}$, and gently stirred to avoid fusion of freshly cut curd cubes and to facilitate whey expulsion. One-third of the whey was removed and stirring was continued for an additional $20 \mathrm{~min}$. Whey was drained and curd was washed with cold $\left(10^{\circ} \mathrm{C}\right)$ water $(50 \mathrm{~g} / \mathrm{kg}$ of curd), held for $10 \mathrm{~min}$, drained, and curd stirred for $10 \mathrm{~min}$ to facilitate further whey expulsion. The curd was salted in 3 applications, 5 min apart, and placed in a bowl chopper (Hobart, Troy, $\mathrm{OH}$ ). Sufficient melted butter $(45,30,15$, or $0 \mathrm{~g} / \mathrm{kg}$ of curd) was added to produce cheeses with a total of $6 \%$ fat (e.g., $15 \mathrm{~g}$ of butter $/ \mathrm{kg}$ was added to curd that contained $45 \mathrm{~g}$ of fat $/ \mathrm{kg}$ ), along with $10 \mathrm{~g}$ of glucono- $\delta$-lactone (GDL; ConAgra Foods Inc., North Liberty, IA) per $1 \mathrm{~kg}$ of curd to slowly lower cheese $\mathrm{pH}$ to 5.2. The GDL and butter were mixed with the curd as the curd was comminuted for $30 \mathrm{~s}$ to particles about 1 to $4 \mathrm{~mm}$ in size in the bowl chopper. The cheese was packed into 9-kg stainless steel hoops, and pressed overnight at $100 \mathrm{kPa}$. The vacuum-packaged cheese blocks were designated no butter (NB), 15 (1.5B), 30 (3B), and 45 (4.5B) $\mathrm{g}$ of butter $/ \mathrm{kg}$, respectively, based on the level of butter added during comminuting (i.e.,). The blocks were stored at $3{ }^{\circ} \mathrm{C}$ until used for analysis. Cheese making was performed in 2 replicates.

\section{Cheese Composition}

Moisture was determined (in triplicate) by weight loss using a microwave oven (CEM Corp., Indian Trail, NC) at $100 \%$ power, with an endpoint setting of $<0.4$ mg weight change over $2 \mathrm{~s}$. Fat content was determined (in duplicate) using a modified Babcock method (Richardson, 1985). Salt was measured by blending grated cheese with distilled water for $4 \mathrm{~min}$ at $260 \mathrm{rpm}$ in a Stomacher 400 (Seward, West Sussex, UK), filtering the slurry through a Whatman \#1 filter paper, and then measuring for chloride content (in triplicate) using a chloride analyzer (model 926, Corning, Medfield, $\mathrm{MA}$ ). The $\mathrm{pH}$ was measured using a glass electrode after stomaching $20 \mathrm{~g}$ of grated cheese with $10 \mathrm{~g}$ of distilled water for $1 \mathrm{~min}$ at $260 \mathrm{rpm}$. Water activity was evaluated on shredded cheese using an AquaLab Lite water activity meter (Decagon, Pullman, WA).

\section{Texture}

Texture profile analysis of the cheese was performed (in triplicate) after 15, 30, 60, and $120 \mathrm{~d}$ of storage using a TA.XTPlus Texture Analyzer (Stable Micro Systems, Godalming, Surrey, UK) equipped with a 2-kg load cell. The cheese textural parameters evaluated were hardness, adhesiveness, cohesiveness, gumminess, springiness, and were calculated as described by Bourne (1968). The cheese samples were cut into cylindrical specimens $(10-\mathrm{mm}$ diameter $\times 20 \mathrm{~mm})$ using a cork borer. The samples were tempered for $1 \mathrm{~h}$ at room temperature $\left(22^{\circ} \mathrm{C}\right)$ before analysis. A 2-bite compression test was conducted with 25 and $60 \%$ compression.

\section{Microstructure}

Cheese samples $(1 \mathrm{~mm} \times 15 \mathrm{~mm} \times 15 \mathrm{~mm})$ were soaked in $2 \mathrm{~g}$ of Nile Red (Sigma-Aldrich, Inc., Saint Louis, MO) per $1 \mathrm{~L}$ of dimethylsulfoxide (Sigma-Aldrich, Inc.) for $5 \mathrm{~min}$ to stain for fat. They then were rinsed twice in water, and stained with $5 \mathrm{~g}$ of fluorescein isothiocyanate (FITC; Sigma-Aldrich, Inc.) per 1 L of acetone-water (1:1) solution to stain for protein. Stained samples were mounted on standard microscope slides with glycerin jelly (nonfluorescent observation medium), coverslipped and placed on an inverted microscope (Model MRC 23, Biorad, Hercules, CA). Laser scanning confocal microscopy (LSCM) was performed using a $\mathrm{Kr} / \mathrm{Ar}$ laser to excite FITC at $488 \mathrm{~nm}$ and Nile Red at $568 \mathrm{~nm}$. Fluorescent emissions were from 488 to $650 \mathrm{~nm}$ and 550 to $750 \mathrm{~nm}$ for FITC and Nile Red, respectively, and captured sequentially using exclusion 
Table 1. Mean $( \pm \mathrm{SE})$ composition of low-fat Mozzarella cheeses made by combining comminuted cheese curd containing about $6 \%, 4.5 \%, 3 \%$, and $1.5 \%$ fat with $0 \%, 1.5 \%, 3 \%$ and $4.5 \%$ melted butter $(\mathrm{NB}, 1.5 \mathrm{~B}, 3 \mathrm{~B}$, and $4.5 \mathrm{~B}$, respectively)

\begin{tabular}{lcccc}
\hline & \multicolumn{4}{c}{ Treatment } \\
\cline { 2 - 5 } Parameter & $\mathrm{NB}$ & $1.5 \mathrm{~B}$ & $3 \mathrm{~B}$ & $4.5 \mathrm{NB}$ \\
\hline Moisture (\%) & $55.1 \pm 1.0$ & $52.1 \pm 1.4$ & $54.8 \pm 2.4$ & $56.0 \pm 1.8$ \\
Fat (\%) & $5.5 \pm 0.2$ & $5.8 \pm 0.3$ & $5.7 \pm 0.4$ & $5.5 \pm 0.3$ \\
pH & $5.10 \pm 0.10$ & $5.10 \pm 0.00$ & $5.20 \pm 0.10$ & $5.10 \pm 0.10$ \\
Salt (\%) & $1.70 \pm 0.10$ & $1.70 \pm 0.10$ & $1.80 \pm 0.10$ & $1.70 \pm 0.10$ \\
\hline
\end{tabular}

filters of 512 to $532 \mathrm{~nm}$, and $\geq 585 \mathrm{~nm}$. Images were false colored with fat as orange and protein as green.

\section{Meltability}

Meltability of cheeses was measured using a UW meltmeter (University of Wisconsin, Madison) as described by Wang et al. (1998). Meltability was expressed as the percentage change in height of cheese sample (7-mm thickness and $30-\mathrm{mm}$ diameter) after $16 \mathrm{~s}$ at a constant force of $0.33 \mathrm{~N}$, when heated to $65^{\circ} \mathrm{C}$.

\section{Pizza Baking and Fork Test}

Stretchability was measured at 15, 30, 60, and 120 $\mathrm{d}$ of storage using a fork test (Gunasekaran and $\mathrm{Ak}$, 2003), after baking Mozzarella cheese on a pizza crust. Cheese samples were mechanically shredded (Presto Professional Salad Shooter, Model 02970, Madison, WI). A 30-cm frozen pizza crust (Rich products Corp., Buffalo, NY) was thawed, $16 \mathrm{~g}$ of tomato pizza sauce (Ragu Traditional Old World Style; Van Den Bergh Foods Co., Lisle, IL) was spread over it, and then it was covered with $300 \mathrm{~g}$ of shredded cheese. The pizza was baked in a forced-air convection oven (Impinger model 1132, Fort Wayne, IN) for 6 min at $250^{\circ} \mathrm{C}$. One minute after baking, a stainless steel, 4-pronged fork was inserted into the cheese, then lifted vertically and the distance at which the cheese could be lifted before breaking was measured. Extent of stretch was measured from 3 different places on the pizza.

\section{Free Oil Determination}

Free oil content of the cheese sample was determined using the method of Kindstedt and Rippe (1990) and modified for low-fat cheese by increasing the cheese sample 4-fold. Thirty-six grams of ground cheese sample was weighed into a Babcock bottle and then immersed in boiling water (approximately $93^{\circ} \mathrm{C}$ in Logan, UT) for $8.0 \mathrm{~min}$ to melt the cheese. Distilled water and methanol in a $1: 1$ ratio $\left(20 \mathrm{~mL}\right.$ at $\left.57.5^{\circ} \mathrm{C}\right)$ were immediately added and the bottle was centrifuged (166 $\times g$ at approximately $57.5^{\circ} \mathrm{C}$; Super Babcock centrifuge, Garver Manufacturing Co., Union City, IN) for 10 min. Calculation for free oil content was appropriately modified according to the sample size used. Free oil was expressed on the basis of cheese weight and total fat content of the cheese as both percentage in cheese and percentage in cheese fat

\section{Data Analysis}

All statistical analyses were performed using the statistical procedures of SAS 9.1.3 (SAS Institute, 1999). The experiment was carried out using PROC MIXED with repeated measures. A correlation analysis was also performed using SAS software to correlate the free oil content in the cheese sample with stretchability of the cheese. Significance was declared at $P<0.05$.

\section{RESULTS}

\section{Composition and Appearance}

The composition of the cheeses was similar $(P>$ 0.05 ) and within expectations for low-fat cheese (Table 1 ). The fat content was between 5 and $6 \%$ for all cheeses. The moisture content was within the range of 52 to $56 \%$. The salt content was between 1.7 and $1.8 \%$. The $\mathrm{pH}$ of the cheeses was controlled by the amount of vinegar added before renneting (to acidify milk to $\mathrm{pH}$ 5.90) and the amount of GDL added with the salt (20 $\mathrm{g} / \mathrm{kg}$ ) to the curd. The curd before comminuting was at a $\mathrm{pH}$ of approximately 5.9 , and during pressing and storage, the GDL hydrolyzed slowly such that the curd $\mathrm{pH}$ decreased to about 5.1 when measured at 1 wk after manufacture. The water activity of all cheeses ranged from 0.97 to 0.98 .

All of the cheese blocks were similar in appearance. Some slight differences were observed during shredding of the cheese. The NB cheese produced long shreds. As the level of added butter increased, shreds were shorter and more fines were observed. More sticking of the cheese to the shredder blades occurred as the cheeses became older, and was more pronounced in the 
cheeses made with added butter. Overall, the $3 \mathrm{~B}$ cheese was preferred because it shredded better than the $4.5 \mathrm{~B}$ cheese and had good melting properties.

\section{Texture}

Initial Textural Changes From 15 to 30 d. At $15 \mathrm{~d}$, the control cheese had the highest $(P<0.05)$ cohesiveness (0.60), with cohesiveness decreasing with increasing amount of butterfat added during comminuting (Figure 1A). During storage from 15 to 30 $\mathrm{d}$, the cheeses with added butter (i.e., 1.5B, 3B, and $4.5 \mathrm{~B})$ apparently underwent further knitting and their cohesiveness at $30 \mathrm{~d}$ became similar to the control NB cheese, whereas the NB cheese had reached its maximum knitting within $15 \mathrm{~d}$, because its cohesiveness did not change after $15 \mathrm{~d}$.

At $15 \mathrm{~d}$, the NB and 1.5B cheeses, when compressed $60 \%$, had similar hardness scores and were significantly different compared with the 3B and 4.5B cheeses (Figure 1B). However, if the cheeses were only compressed $25 \%$, then no difference in hardness scores was observed (data not shown). Thus, hardness (which is the maximum load exerted during compression) depends on how well the comminuted curd particles are knitted together. Hardness increased slightly between 15 to 30 $\mathrm{d}$, except for the cheese (4.5B) with the highest level of added butter.

For cheese gumminess, the control NB cheese had similar values to that of the $1.5 \mathrm{~B}$ cheese but higher values $(P<0.05)$ than did $3 \mathrm{~B}$ and $4.5 \mathrm{~B}$ cheeses (Figure $1 \mathrm{C})$ at $15 \mathrm{~d}$ of storage. Gumminess is calculated as the product of hardness and cohesiveness (Bourne, 1968) and these differences in gumminess at 15 and $30 \mathrm{~d}$ were a function of changes in both cohesiveness and hardness. The NB cheese did not show a change in gumminess, whereas the $3 \mathrm{~B}$ cheese increased in gumminess from 15 to $30 \mathrm{~d}$ due to increase in both hardness and cohesiveness. Some differences in adhesiveness were observed with large differences at $15 \mathrm{~d}$ and the cheeses with the highest amount of butter added (i.e., 4.5B) had the lowest adhesiveness values (Figure 1D).

Textural Changes After $30 \mathrm{~d}$. The cohesiveness of added butter cheeses (i.e., 1.5B, 3B, and 4.5B) increased from 30 to $120 \mathrm{~d}$ of storage and was between 0.60 to 0.80 for all samples by $120 \mathrm{~d}$ (Figure 1A). This is similar to the cohesiveness of full-fat cheese (Awad et al., 2005). This implies increased adhesion between cheese particles, presumably from knitting together of curd particles during aging. The hardness scores of control NB cheese were similar to those of $1.5 \mathrm{~B}$ cheese (Figure 1B); however, the 4.5B cheese was still the lowest in hardness $(P<0.05)$.
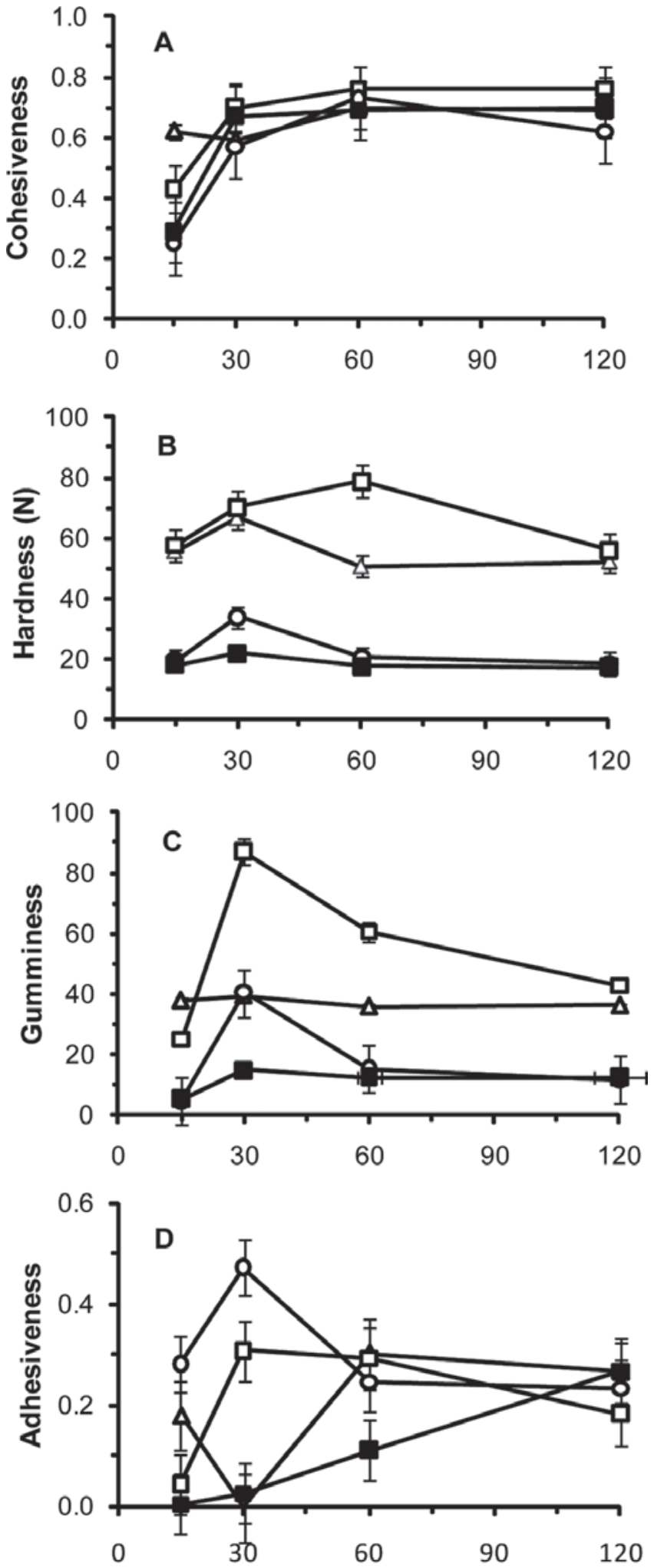

Figure 1. Texture profile measurements of (A) cohesiveness, (B) hardness, (C) gumminess, and (D) adhesiveness for low-fat Mozzarella cheeses made from repressed comminuted cheese with $0 \%(\mathrm{NB}, \Delta)$, $1.5 \%(1.5 \mathrm{~B}, \square), 3 \%(3 \mathrm{~B}, \bigcirc)$, or $4.5 \%(4.5 \mathrm{~B}, \mathbf{\square})$ added butter, respectively, after $15,30,60$, and $120 \mathrm{~d}$ of storage. 

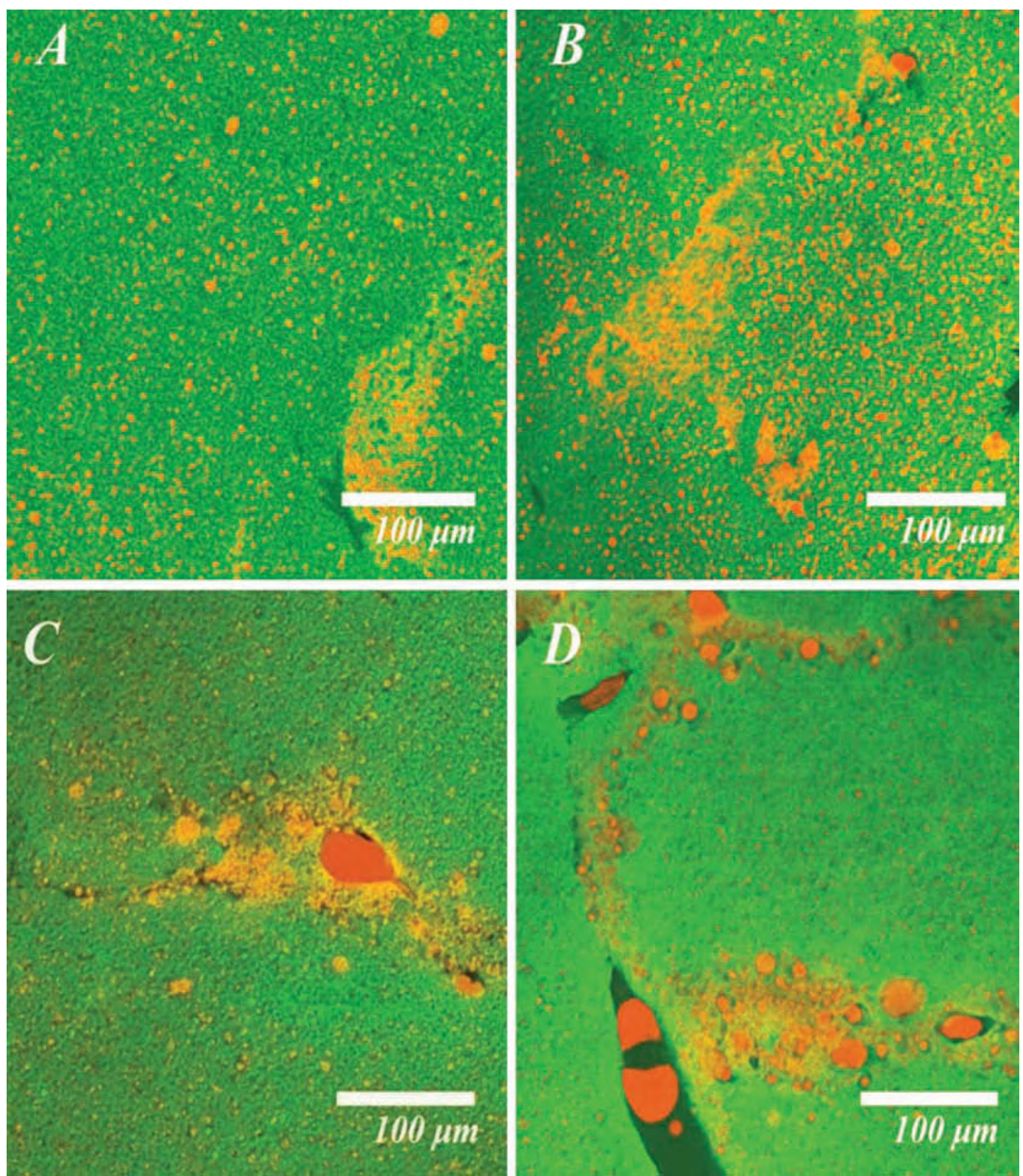

Figure 2. Laser scanning confocal micrographs for low-fat Mozzarella cheese made from repressed comminuted curd with (A) $0 \%$, (B) $1.5 \%$, (C) $3 \%$, and (D) $4.5 \%$ of added butter after $2 \mathrm{wk}$ of storage. Green $=$ protein, orange/yellow $=$ fat.

The gumminess of all cheese samples is presented in Figure 1C. As the added butterfat content increased, a decrease in gumminess occurred, especially in the $3 \mathrm{~B}$ and 4.5B cheeses. Adhesiveness was initially similar for all of the cheeses and increased during storage (Figure 1D). Significant difference in adhesiveness occurred at $30 \mathrm{~d}$, but by $120 \mathrm{~d}$, no difference was present. Zisu and Shah (2007) also reported an increase in adhesiveness during storage. Springiness was not significantly different for all cheeses and remained at $0.81 \pm 0.02$ throughout storage. Similar observations on springi- ness in Mozzarella cheese was reported by Yun et al. (1993).

\section{Microstructure}

Both fat and protein were imaged using LSCM and representative microstructural images for control and treated cheese samples are shown in Figure 2. When fat droplets were present that were larger than the plane of focus (and, thus, completely filled the focal plane), they appeared orange in color in the composite image 
produced by merging Nile red and FITC fluorescence channels. In contrast, small fat droplets appear yellow because they only fill a portion of the plane of focus, with the remainder being filled by protein matrix.

No fiber structure was observed in the cheeses because the cheese was made without using the pasta filata process. Hence, it was similar to the structure of nonfat Mozzarella (Paulson et al., 1998), rather than having fat-serum channels observed in regular Mozzarella cheese (Oberg et al., 1993). Fat was observed as tightly embedded masses within the casein matrix (Figure 2A). Most of the fat droplets in the NB cheese were small, generally less than $3-\mu \mathrm{m}$ diameter with a few larger (approximately 5 to $10 \mu \mathrm{m}$ ). The fat droplets were mainly spherical in shape, with protein matrix (green) occupying most of the micrograph as expected for cheese that consists of approximately $94 \%$ hydrated protein. The areas with some clustering of fat droplets appear to be related to the surface of the comminuted cheese and where 2 curd particles are knitted together.

For cheeses with added butter, the $1.5 \mathrm{~B}$ cheese was similar in microstructure to the NB cheese. In the fields examined using LSCM, we did not observe any differences in structure that could be associated with added fat from butter (Figure 2B). In the 3B cheese, the added fat was apparent (Figure 2C) as larger fat droplets that were not encased within the protein matrix and were dark orange in color. These were located at comminuted curd particle junctions. Such butterfat would remain on the surface of the comminuted curd particles and be trapped between them as the curd was pressed.

The amount of fat droplets located between the curd particles increased with increasing level of added butter (compare Figures $2 \mathrm{~B}$ to $2 \mathrm{D}$ ). In the $3 \mathrm{~B}$ and $4.5 \mathrm{~B}$ cheeses, the butter added during comminuting tended to prevent complete knitting of curd particles and these spaces were visible as black areas in the micrograph (see especially Figure 2C). Thus, the presence of large fat droplets located along curd junctions served the function of creating serum channels in the cheese. In the cheeses with added butter, less fat was trapped within the protein matrix. For example, in the $4 \mathrm{~B}$ cheese, the curd before comminuting only contained approximately $1.5 \%$ fat, with the other approximately $4.5 \%$ fat being added from butter added during comminuting.

\section{Meltability}

Melting of cheese by forced flow $(0.33 \mathrm{~N})$ is shown in Figure 3. At $15 \mathrm{~d}$ of storage, the $3 \mathrm{~B}$ and $4.5 \mathrm{~B}$ cheeses melted more than the $\mathrm{NB}$ and $1.5 \mathrm{~B}$ cheeses, as shown by the larger decrease in cheese height during the melt test (Figure 3A). Cheeses with $\geq 50 \%$ of the fat added during comminuting, and with sufficient fat present
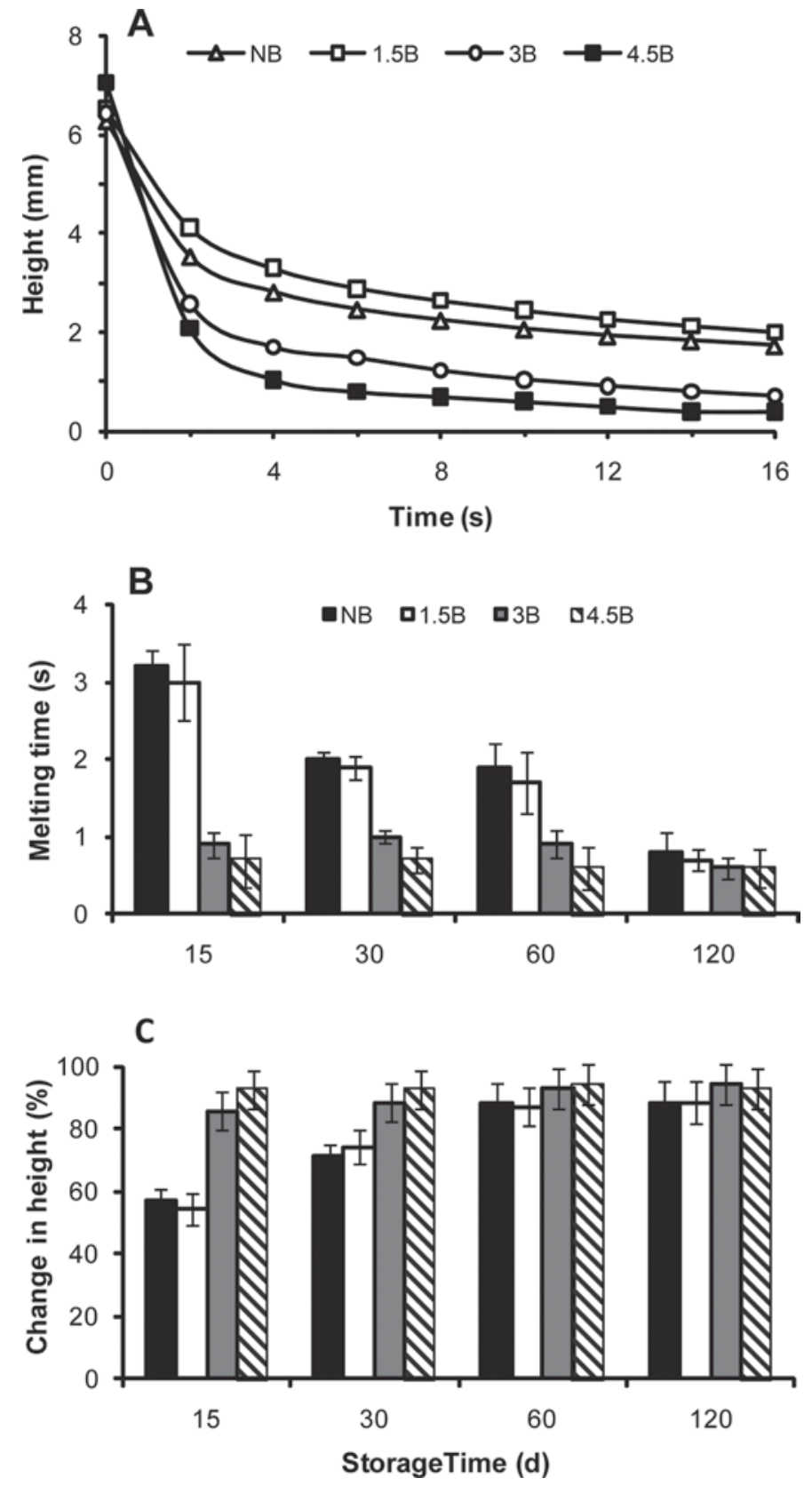

Figure 3. Melting of low-fat Mozzarella cheese at $65^{\circ} \mathrm{C}$ under forced-flow conditions showing (A) change in cheese height during 16 $\mathrm{s}$ for cheese aged for $15 \mathrm{~d}$, (B) time to achieve a $50 \%$ decrease in cheese height for cheese stored for 15, 30, 60, and $120 \mathrm{~d}$, and (C) total decrease in cheese height for $16 \mathrm{~s}$ as measured in a UW meltmeter (University of Wisconsin, Madison). Cheeses (NB, 1.5B, 3B, and 4.5B) were made with $0 \%, 1.5 \%, 3 \%$, and $4.5 \%$ butter added during comminuting, respectively. Error bars $=$ SEM.

between curd particles (i.e., 3B and 4.5B, as shown in Figure 2), had better melt characteristics (Figure 3). Melting of $3 \mathrm{~B}$ and $4.5 \mathrm{~B}$ cheeses was faster than that of the $1.5 \mathrm{~B}$ and $\mathrm{NB}$ cheeses as shown in Figure $3 \mathrm{~A}$, and the time taken for the cheese height to decrease by $50 \%$ was shorter (Figure $3 \mathrm{~B}$ ). At $15 \mathrm{~d}$, the $3 \mathrm{~B}$ cheese 


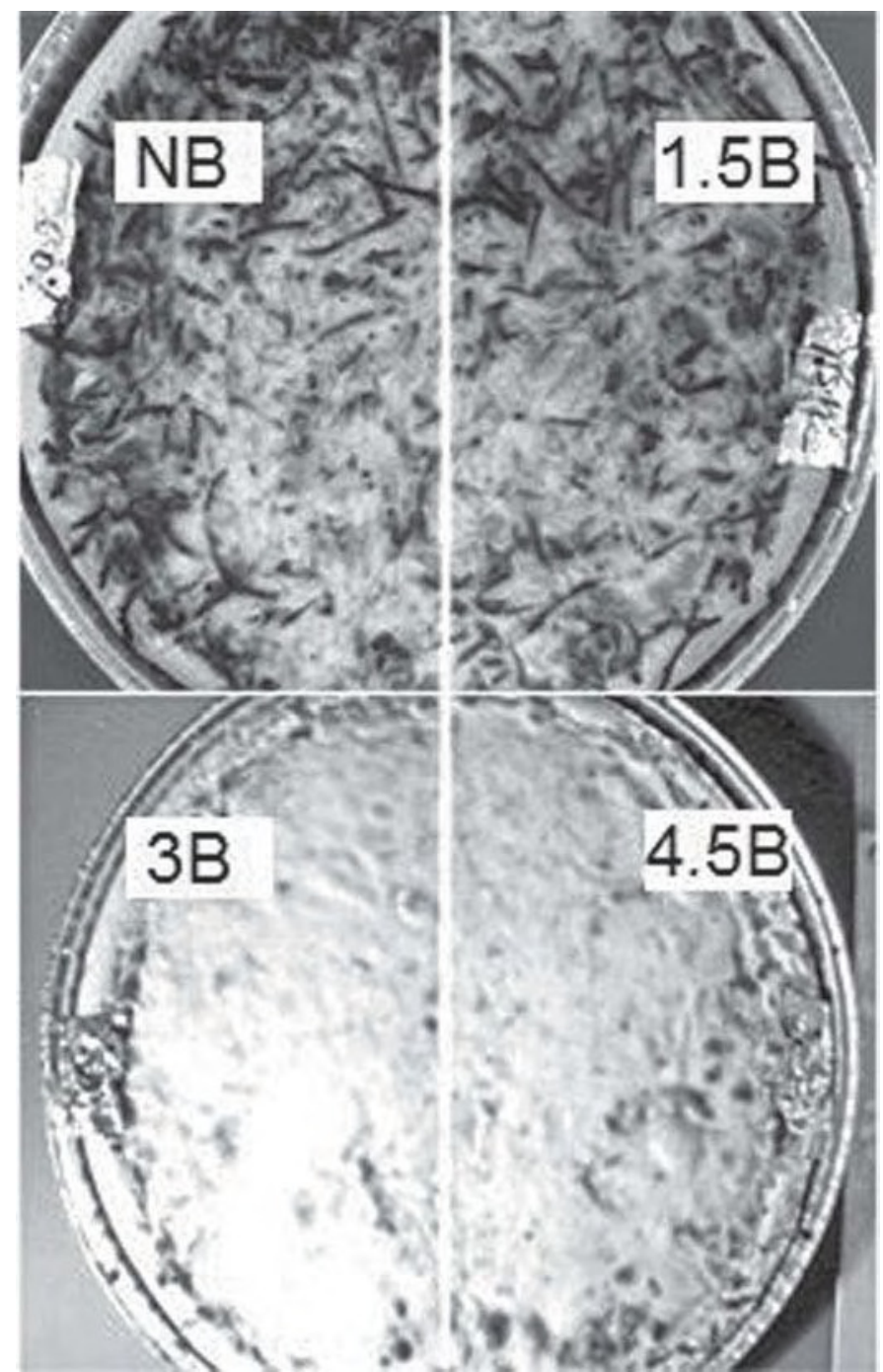

Figure 4. Low-fat Mozzarella cheese baked on pizza crust at $250^{\circ} \mathrm{C}$ for 6 min. Cheeses were made with $0 \%$ butter, NB; $1.5 \%$ butter, $1.5 \mathrm{~B}$; $3 \%$ butter, $3 \mathrm{~B}$; and $4.5 \%$ butter, $4.5 \mathrm{~B}$, added to comminuted curd during manufacture.

had flowed sufficiently within approximately $0.8 \mathrm{~s}$ for its height to decrease by $50 \%$, whereas the NB cheese required $3 \mathrm{~s}$.

Similarly, the extent of melting after $16 \mathrm{~s}$ was greatest for the 3B and 4.5B cheeses (Figure 3C). For 15-dold cheese, $\mathrm{NB}$ and $1.5 \mathrm{~B}$ cheeses only had approximately $55 \%$ and approximately $45 \%$ height decrease, respectively, whereas $3 \mathrm{~B}$ and $4.5 \mathrm{~B}$ cheeses had height decreases of $>80 \%$. On further storage for $30 \mathrm{~d}$, increased flow occurred for the control NB cheese and $1.5 \mathrm{~B}$ cheese, with a height decrease of approximately $70 \%$, whereas flow of the $3 \mathrm{~B}$ and $4.5 \mathrm{~B}$ cheeses melting remained unchanged.
Table 2. Mean stretch (cm) measured using the fork test after baking low-fat Mozzarella cheeses (NB, 1.5B, 3B, and 4.5B) on a pizza in a convection oven

\begin{tabular}{lllll}
\hline & \multicolumn{4}{c}{ Cheese $^{1}$} \\
\cline { 2 - 5 } $\begin{array}{l}\text { Storage } \\
\text { time (d) }\end{array}$ & NB & $1.5 \mathrm{~B}$ & $3 \mathrm{~B}$ & $4.5 \mathrm{~B}$ \\
\hline 15 & $6.3^{\mathrm{c}}$ & $5.0^{\mathrm{c}}$ & $36.7^{\mathrm{a}}$ & $33.0^{\mathrm{a}}$ \\
30 & $9.0^{\mathrm{b}}$ & $9.3^{\mathrm{b}}$ & $12.3^{\mathrm{b}}$ & $16.0^{\mathrm{b}}$ \\
60 & $7.0^{\mathrm{c}}$ & $6.3^{\mathrm{c}}$ & $10.3^{\mathrm{b}}$ & $10.0^{\mathrm{b}}$ \\
120 & $6.0^{\mathrm{c}}$ & $6.7^{\mathrm{c}}$ & $12.7^{\mathrm{b}}$ & $37.3^{\mathrm{a}}$ \\
\hline
\end{tabular}

${ }^{\mathrm{a}-\mathrm{c}}$ Means with common letters were not significantly different $(\alpha=$ $0.05)$.

${ }^{1} \mathrm{NB}=0 \%$ butter, $1.5 \mathrm{~B}=1.5 \%$ butter, $3 \mathrm{~B}=3 \%$ butter, and $4.5 \mathrm{~B}=$ $4.5 \%$ butter added to comminuted curd during manufacture.

\section{Stretchability}

After baking on a pizza in the convection oven, the NB cheese had poor melt, with the shreds of cheese still being evident and having a partially charred surface (Figure 4). In contrast, the experimental cheeses (especially $3 \mathrm{~B}$ and $4.5 \mathrm{~B}$ ) had improved performance, with the shreds softening and flowing to form a mass of melted cheese during baking (Figure 4). This resulted in increased length of stretch of the $3 \mathrm{~B}$ and $4.5 \mathrm{~B}$ cheeses (Table 2) when the pizza fork test was performed. The distance that cheese strands could be lifted from the pizza was observed to be increasing with increasing level of butterfat added during comminuting of the cheese curd. The fusion of these cheese shreds was related to the apparent retardation of dehydration of the cheese during baking. This improved melting (and stretch) of the experimental cheeses was comparable to spraying oil onto low-fat cheese before baking (Rudan and Barbano, 1998).

\section{Free Oil}

The free oil content of the control and experimental cheeses is depicted in Figure 5. At each storage time, a linear correlation between added butterfat and free oil $\left(\mathrm{R}^{2} \geq 0.92\right)$ was present. The free oil was assumed to originate from the oil-serum channels observed in the microstructure of the comminuted cheeses (Figure 2 ). As the cheeses aged from 15 to $120 \mathrm{~d}$, their free oil content decreased. This is opposite to what normally happens in Mozzarella cheese, with free oil increasing during storage (Cortez et al., 2008). A similar increase in free oil had been observed when low-moisture Mozzarella cheese was blended with non-pasta filata cheese (Kiely et al., 1992). 


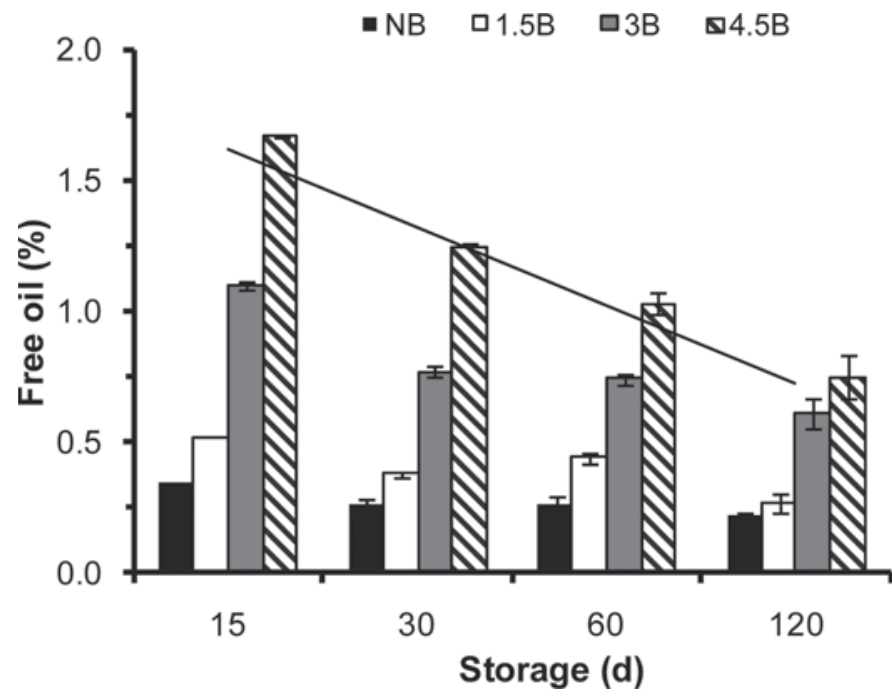

Figure 5. Correlation of free oil content of low-fat Mozzarella cheeses with $0 \%, 1.5 \%, 3 \%$, or $4.5 \%$ added butter $(\mathrm{NB}, 1.5 \mathrm{~B}, 3 \mathrm{~B}$, and $4.5 \mathrm{~B}$, respectively) with storage time $\left(\mathrm{R}^{2}=0.98\right.$ for cheese $\left.4.5 \mathrm{~B}\right)$.

\section{DISCUSSION}

\section{Texture}

Textural changes in the low-fat comminuted repressed cheese are slightly different and texture measurement by texture profile analysis can be explained as shown in Figure 6. Measured values of hardness, cohesiveness, and springiness are a function of how the cheese deforms and possible internal rearrangement of particles and slippage when the cheese undergoes compression (which in this study was $60 \%$ of the height of the cheese sample). In a high-fat cheese, the abundance of fat droplets provides points of matrix weakness, allowing slippage during compression. This allows deformation of the cheese without fracture occurring. These changes occur on a microstructural level and the cheese retains considerable cohesiveness (i.e., a second compression also requires about $60 \%$ of the work of the first compression)

In a low-fat cheese that contains only $6 \%$ fat, less opportunity exists for slippage (because of less fat) and macrostructural fractures occur. The unfractured protein matrix network, however, retains elasticity and the cheese rebounds to a similar level as that of the high-fat cheese. This is measured as springiness, or the fraction of initial height of the cheese sample regained after compression. Both full-fat and low-fat cheeses typically have a springiness of $80 \%$ of their original height when measured using 60\% compression (data not shown).

However, during a second compression, the low fat cheese is easily recompressed along the same fracture lines and a lower cohesiveness value is obtained. When low-fat cheese was comminuted and butterfat added, no large fracture lines were observed in the cheese. Apparently, slippage occurred between cheese particles as the cheese was compressed. This resulted in the comminuted and repressed low-fat cheeses having similar springiness and cohesiveness measurements as their higher-fat counterpart.

All of the low-fat Mozzarella cheeses made during this research felt similar in firmness when manually examined, and slightly softer than a typical low-moisture part skimmed Mozzarella cheese. They did not have the hard rubbery texture that often occurs in low-fat cheeses (Awad et al. 2005; Dong et al. 2009) and matched fullfat Mozzarella cheese texture as reported by Bhaskaracharya and Shah (1999). This was attributed to the high moisture (52 to $53 \%$ ) content and decreased calcium levels obtained by using direct acidification (Breene et al. 1964; McMahon and Oberg, 2000). In this regard, the low-fat Mozzarella was similar to whole-fat Mozzarella cheese that is also commonly made using direct acidification, although without the addition of GDL during salting (Francolino et al., 2010).

The hardness of Mozzarella cheese has been reported to decrease with increase in moisture content (Bhaskaracharya and Shah, 1999). The increase in hardness during storage, thus, might result from a decrease in the level of free water in the cheese, which increases cheese resistance to deformation as previously reported (McMahon et al., 1999; Beal and Mittal, 2000). Ac-

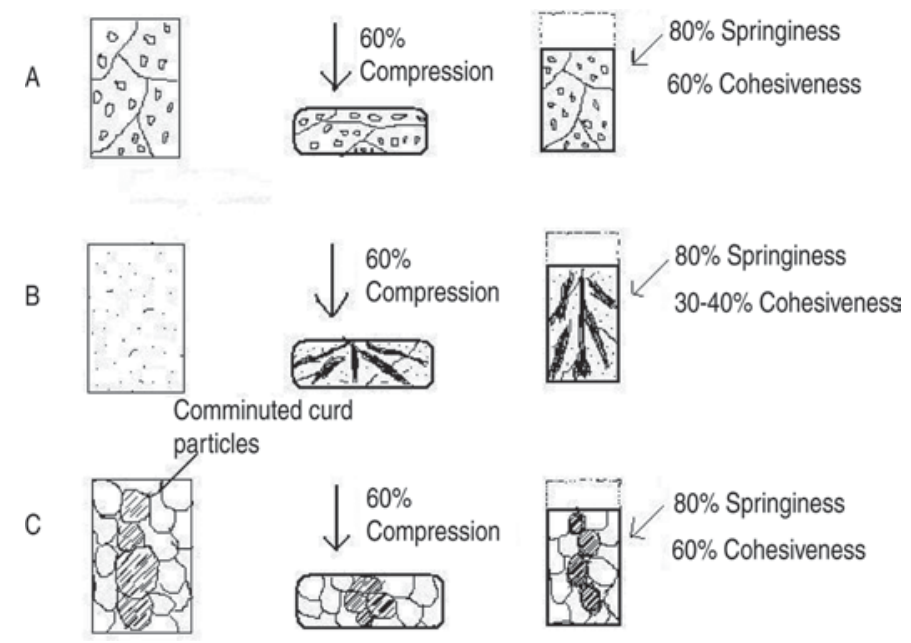

Figure 6. Comparison of cheese microstructure as affected by fat and comminuting during texture profile analysis. (A) Full-fat cheese (33\% fat), protein network deformation, and slippage around fat droplets (approximately $10 \mu \mathrm{m})$. (B) Low-fat noncomminuted cheese $(6 \%$ fat), protein network deformation only, and brittle fracture. (C) Lowfat comminuted repressed cheese $(6 \%$ fat), protein network deformation, and slippage around comminuted cheese particles (shaded particles to explain the direction and pattern of slippage). 
cording to Lawrence et al. (1987), cheese texture development is accomplished in 2 stages during ripening. Within the first 2 wk of storage, the cheese changes from having a rubbery texture to a smoother texture and a less curdy and more homogenous product. During this time, the casein network weakens as proteolysis occurs by residual coagulant in the cheese. Subsequently, a further gradual change in cheese texture occurs as proteolysis continues under the combined influence of the coagulant and starter and nonstarter bacterial enzymes and (Mendia et al., 2000; Martínez-Cuesta et al., 2001; Attaie, 2005).

The change in cohesiveness measurements during storage of the comminuted cheeses comes about because compression of the cheese depends on how well the comminuted cheese particles knit together, as well as deformation of the cheese protein network structure. It appears that adding butterfat during comminuting interferes with the ability of the curd particles to knit together.

Typically, lowering fat content in Mozzarella cheese causes an increase in hardness (Awad et al., 2005). The softer texture of our low-fat cheeses was attributed to (1) using direct acidification (McMahon and Oberg, 1998), (2) comminuting the cheese, and (3) adding a portion of the butterfat after curd manufacture. Such butterfat addition significantly $(P<0.05)$ increased cohesiveness (Figure 1A) and decreased hardness (Figure 1B) compared with the control NB cheese.

\section{Microstructure}

From the microstructural appearance of the cheeses, it was the 2-phase distribution of fat within the cheese that increased the availability of fat that could be expressed onto the shred surface. The higher levels of fat both in quantity and fat droplet size in a free form occurred at the new grain boundaries created by the comminuting of the cheese. This enabled these lowfat cheeses with added butter to behave like a full-fat cheese where portions of the fat droplets can be easily expressed from the cheese.

In full-fat cheese varieties, fat droplets can be damaged during cheesemaking and storage, breaking the milk fat globule membrane (MFGM) material that originally encases the fat droplets (Oberg et al., 1993; Lopez et al., 2006; McMahon et al., 2009). This may result in a large pool of free oil within the cheese matrix that can be easily expressed from the cheese. When this occurs during heating of the cheese during baking on pizza crust, the rate of water loss from the cheese via dehydration is decreased (Rudan and Barbano, 1998). However, low-fat cheese lacks the required threshold amount of fat for such fat pooling to occur, resulting in little disruption of MFGM and fat droplets completely encased within the protein matrix.

The addition of butterfat to the cheese during the later stages of cheesemaking after the curd has been formed or after a cheese block has been pressed, simulates in low-fat cheese the function of the pools of non-MFGM-encased fat (or aggregates of fat globules) found in full-fat cheese. This provides a source of fat in the cheese that is not protected by the MFGM and susceptible to oiling off or removal.

\section{Melting}

Cheeses made using direct acidification inherently melt well because of their decreased calcium content (McMahon et al., 2005) and this was further enhanced by the presence of fat that was not entrapped within the protein matrix. As shown in Figures $2 \mathrm{C}$ and $2 \mathrm{D}$, a relatively large amount of butterfat was present between the curd particles, and it appears that this fat acted as a lubricant when the cheese was heated, allowing the $3 \mathrm{~B}$ and $4.5 \mathrm{~B}$ cheeses to flow rapidly at $65^{\circ} \mathrm{C}$. In the $1.5 \mathrm{~B}$ cheese, no large droplets of fat were evident (Figure 2B) and no apparent lubricating effect occurred; therefore, it melted similarly to the control NB cheese.

As the cheeses aged, the NB and 1.5B cheeses melted more rapidly and this was attributed to proteolysis, as has been previously shown (Lucey et al., 2003). With such increased flowability of the protein matrix, the lubricating effect of the added butter was of less relevance to overall melting. After $60 \mathrm{~d}$ of storage, all of the cheeses had melted to the same extent (Figure 3C), which probably represented the instrumental limitations of measuring melt by the forced-flow method we used.

\section{Stretchability}

The result of stretchability measurements were in agreement with the results obtained by Rudan and Barbano (1998) when they tested vegetable oil spray on nonfat cheese shreds on pizza crust during baking. However, in this study, the hydrophobic coating was provided inside cheese and not applied externally. This could be described as the low-fat cheese containing veins of fat that can be released to the surface of the cheese during heating. The effect of this probable migration of fat from inside channels to the cheese surface came into play during pizza baking and resulted in the surface of the cheese shreds being covered in a film of oil as described in Figure 7. The increased level of added butterfat, particularly in $3 \mathrm{~B}$ and $4.5 \mathrm{~B}$ cheeses, 


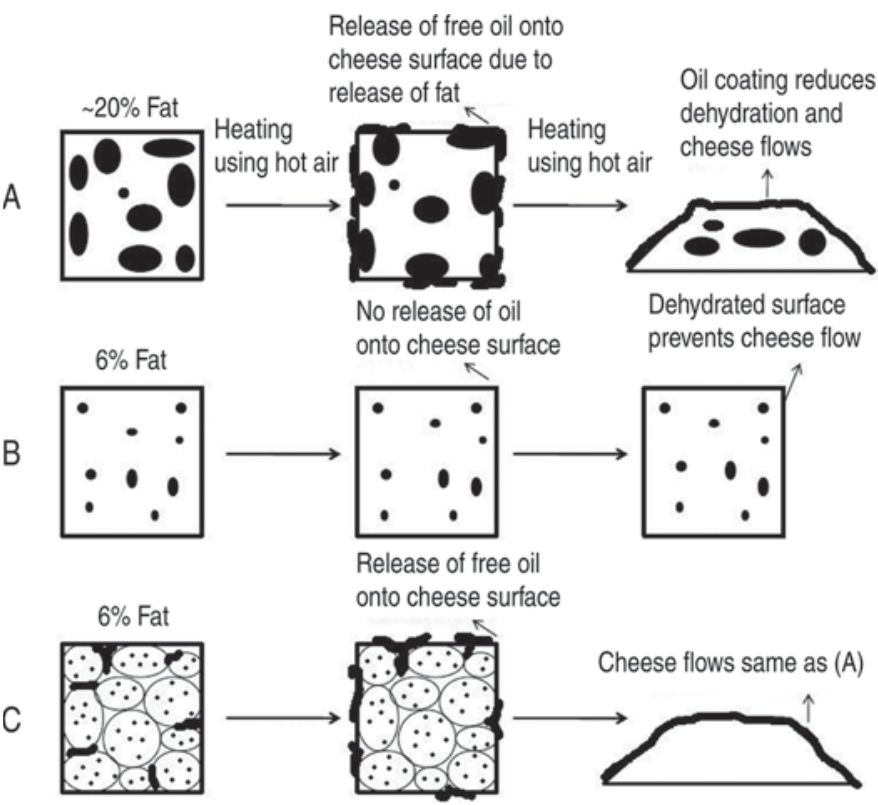

Figure 7. Model of melting of cheese in a hot-air convection oven showing release and nonrelease of oil onto surface of (A) a typical pizza cheese containing approximately $20 \%$ fat, (B) a low-fat cheese containing $6 \%$ fat, made using conventional methods, and (C) a low-fat cheese in which a portion of the butterfat is located between comminuted cheese particles, containing $6 \%$ fat in total.

matched the meltability of Mozzarella cheese containing approximately $20 \%$ fat (data not shown), whereas $\mathrm{NB}$ and $1.5 \mathrm{~B}$ cheese did not melt well on pizza.

\section{Free Oil}

The comminuting method produced some free fat that was not encased within the protein matrix as the curd particles were cut during comminuting and, thus, came out to be approximately $0.3 \%$ in control NB cheese (i.e., $5 \%$ of total fat was as free oil). For the cheeses made with added butter, we calculated that about $40 \%$ of the added butterfat was expressible. This decreased to $25 \%$ after $60 \mathrm{~d}$ of storage. In comparison, about $20 \%$ of the butterfat in low-moisture part skim Mozzarella cheese is typically expressible as free oil (Kindstedt and Rippe, 1990). The percentage of free oil in Mozzarella cheese that is expressible decreases with decreasing fat content, and for a low-fat cheese would be expected to be only about $5 \%$. This amounts to only $3 \mathrm{mg}$ of oil being expressible per gram of cheese, whereas in the $3 \mathrm{~B}$ cheese, about $12 \mathrm{mg}$ of oil was initially expressible. It has been observed that about $10 \mathrm{mg}$ of oil per gram of cheese needs to be expressed during baking of a pizza to prevent excessive dehydration, skin formation, and charring of the cheese (P. S. Kindstedt, University of Vermont, Burlington; personal communication). Thus, a low-fat Mozzarella cheese made from milk containing approximately $0.7 \%$ fat (e.g., cheese NB) in which all of the fat is entrapped within the protein matrix, does not reach the required level of oil release during baking to prevent excessive dehydration. By making curd that has 1 to $3 \%$ fat and then adding additional fat in an easily expressible form, a cheese that meets the standard of being low fat (i.e., no more than $6 \%$ fat) can be produced that has sufficient oil release during baking to prevent the excessive dehydration and allow it to melt into a cohesive mass rather than remaining as shreds.

The decreased level of free oil in 3B and 4.5B cheeses during storage implies that the fat in comminuted and repressed cheese is becoming more entrapped in the cheese matrix as the cheese ages. During storage, progressive knitting together of the comminuted curd particles occurs, as shown by the increase in cohesiveness between d 15 and 30 . Hence, more oil remains trapped within the cheese and the amount of free oil decreases. Only those fat droplets near the surface of cheese shreds would be easily released into the water used during the free oil analysis, or if an open channel between curd granules is present that allows movement of fat from the interior of the shreds to the surface.

\section{CONCLUSIONS}

In conclusion, addition of melted butter to low-fat Mozzarella cheese curd made using a direct acidification method, followed by pressing into a coherent cheese block, decreased the quick dehydration of shredded cheese during pizza baking. The availability of fat in a more easily expressible form provided an increase in desirable melting and baking properties of pizza cheese. Low-fat cheese in which 30 and $45 \mathrm{~g}$ of melted butter/ $\mathrm{kg}$ was added to curd containing 30 and $15 \mathrm{~g}$ of fat $/ \mathrm{kg}$, respectively, had comparatively better meltability and stretchability along with better baking properties than a conventionally produced cheese in which all of the fat was trapped within the curd protein matrix. Addition of $15 \mathrm{~g}$ of melted butter $/ \mathrm{kg}$ to cheese curd containing $45 \mathrm{~g}$ of fat $/ \mathrm{kg}$ did not have increased meltability and stretchability and remained similar to the control cheese. This was because it did not have sufficient expressible oil to coat the surface of the cheese shreds during baking in a pizza oven.

\section{ACKNOWLEDGMENTS}

The authors thank David Irish, processing specialist at the Western Dairy Center, Utah State University, for technical assistance and cheesemaking. Financial support for this research was provided by Dairy Man- 
agement, Inc. (Rosemont, IL) as administered by the Dairy Research Institute. This research was supported by the Utah Agricultural Experiment Station, Utah State University, Logan, and approved as journal paper No. 8264.

\section{REFERENCES}

Attaie, R. 2005. Effects of aging on rheological and proteolytic properties of goat milk Jack Cheese produced according to cow milk procedures. Small Rumin. Res. 57:19-29.

Awad, S., A. N. Hassan, and K. Muthukumarappan. 2005. Application of exopolysaccharide-producing cultures in reduced-fat Cheddar cheese: Texture and melting properties. J. Dairy Sci. 88:42044213.

Barz, R. L., and C. P. Cremer. 1993. Process of making acceptable Mozzarella cheese without aging. Leprino Foods Co., assignee. US Patent 5,200,216.

Beal, P., and G. S. Mittal. 2000. Vibration and compression responses of Cheddar cheese at different fat content and age. Milchwissenschaft 55:139-142.

Bhaskaracharya, R. K., and N. P. Shah. 1999. Texture evaluation of commercial mozzarella cheeses. Aust. J Dairy Technol. 54:3640.

Bourne, M. C. 1968. Texture profile of ripening pears. J. Food Sci. $33: 223-226$.

Breene, W. M., W. V. Price, and C. A. Ernstrom. 1964. Changes in composition of Cheddar cheese curd during manufacture as a guide to cheese making by direct acidification. J. Dairy Sci. $47: 840-848$.

Cortez, M. A. S., M. M. Furtado, M. L. Gigante, and P. S. Kindstedt. 2008. Effect of $\mathrm{pH}$ on characteristics of low-moisture Mozzarella cheese during refrigerated storage. J. Food Sci. 73:S443-S448.

Dong, J.-Y., L.-J. Chen, J.-L. Maubois, and Y. Ma. 2009. Influence of medium-concentration factor microfiltration treatment on the characteristics of low-moisture Mozzarella cheese. Dairy Sci. Technol. 89:139-154.

Francolino, S., F. Locci, R. Ghiglietti, R. Iezzi, and G. Mucchetti. 2010. Use of milk protein concentrate to standardize milk composition in Italian citric Mozzarella cheese making. LWT Food Sci. Technol. 43:310-314.

Guinee, T. P., E. P. Feeney, M. A. E. Auty, and P. F. Fox. 2002. Effect of $\mathrm{pH}$ and calcium concentration on some textural and functional properties of Mozzarella cheese. J. Dairy Sci. 85:1655-1669.

Gunasekaran, S., and M. M. Ak. 2003. Measuring cheese stretchability. Pages 377-397 in Cheese Rheology and Texture. CRC Press, Boca Raton, FL.

Joshi, N. S., K. Muthukumarappan, and R. I. Dave. 2003a. Effect of calcium on physicochemical properties of fat-free Mozzarella cheese. J. Food Sci. 68:2289-2294.

Joshi, N. S., K. Muthukumarappan, and R. I. Dave. 2003b. Understanding the role of calcium in functionality of part skim Mozzarella cheese. J. Dairy Sci. 86:1918-1926.

Joshi, N. S., K. Muthukumarappan, and R. I. Dave. 2004. Effects of reduced-calcium, test temperature and storage on stretchability of part-skim Mozzarella cheese. Aust. J. Dairy Technol. 59:60-65.

Kiely, L. J., S. L. McConnell, and P. S. Kindstedt. 1992. Melting behavior of Mozzarella/non-Mozzarella cheese blends. Cult. Dairy Prod. J. 27:24-29.

Kindstedt, P. S., and J. K. Rippe. 1990. Rapid quantitative test for free oil (oiling off) in melted Mozzarella cheese. J. Dairy Sci. 73:867-873.

Lawrence, R. C., L. K. Creamer, and J. Gilles. 1987. Texture development during cheese ripening. J. Dairy Sci. 70:1748-1760.

Lopez, C., V. Briard-Bion, B. Camier, and J. Y. Gassi. 2006. Milk fat thermal properties and solid fat content in Emmental cheese: A differential scanning calorimetry study. J. Dairy Sci. 89:2894-2910.
Lucey, J. A., M. E. Johnson, and D. S. Horne. 2003. Invited review: Perspectives on the basis of the rheology and texture properties of cheese. J. Dairy Sci. 86:2725-2743.

Martínez-Cuesta, M. C., P. F. de Palencia, T. Requena, and C. Peláez. 2001. Enzymatic ability of Lactobacillus casei ssp. casei IFPL 731 for flavour development in cheese. Int. Dairy J. 11:577-585.

McMahon, D. J., R. L. Fife, and C. J. Oberg. 1999. Water partitioning in Mozzarella cheese and its relationship to cheese meltability. J. Dairy Sci. 82:1361-1369.

McMahon, D. J., M. M. Motawee, and W. R. McManus. 2009. Influence of brine concentration and temperature on composition, microstructure, and yield of feta cheese. J. Dairy Sci. 92:41694179.

McMahon, D. J., and C. J. Oberg. 1998. Influence of fat, moisture and salt on functional properties of Mozzarella cheese. Aust. J. Dairy Technol. 53:98-101.

McMahon, D. J., and C. J. Oberg. 2000. Manufacture of lower-fat and fat-free pizza cheese. US Patent 6,113,953.

McMahon, D. J., B. Paulson, and C. J. Oberg. 2005. Influence of calcium, $\mathrm{pH}$, and moisture on protein matrix structure and functionality in direct-acidified nonfat Mozzarella cheese. J. Dairy Sci. 88:3754-3763.

Mendia, C., F. J. Ibañez, P. Torre, and Y. Barcina. 2000. Effect of pasteurization and use of a native starter culture on proteolysis in a ewes' milk cheese. Food Contr. 11:195-200.

Merrill, R. K., C. J. Oberg, and D. J. McMahon. 1994. A method for manufacturing reduced fat Mozzarella cheese. J. Dairy Sci. 77:1783-1789.

Metzger, L. E., D. M. Barbano, and P. S. Kindstedt. 2001. Effect of milk preacidification on low fat Mozzarella cheese: III. Post-melt chewiness and whiteness. J. Dairy Sci. 84:1357-1366.

Oberg, C. J., W. R. McManus, and D. J. McMahon. 1993. Microstructure of Mozzarella cheese during manufacture . Food Structure $12: 251-258$.

Oommen, B. S., D. J. McMahon, C. J. Oberg, J. R. Broadbent, and M. Strickland. 2002. Proteolytic Specificity of Lactobacillus delbrueckli ssp. bulgaricus influences functional properties of Mozzarella cheese. J. Dairy Sci. 85:2750-2758.

Paulson, B. M., D. J. McMahon, and C. J. Oberg. 1998. Influence of sodium chloride on appearance, functionality and protein arrangements in nonfat Mozzarella cheese. J. Dairy Sci. 81:2053-2064.

Perry, D. B., D. J. McMahon, and C. J. Oberg. 1997. Effect of exopolysaccharide-producing cultures on moisture retention in low fat Mozzarella cheese. J. Dairy Sci. 80:799-805.

Richardson, G. H., ed. 1985. Standard Methods for the Examination of Dairy Products. 15th ed. Am. Publ. Health Assoc. Inc., Washington, DC.

Rudan, M. A., and D. M. Barbano. 1998. A model of Mozzarella cheese melting and browning during pizza baking. J. Dairy Sci. 81:2312-2319.

SAS Institute. 1999. SAS User's Guide: Statistics version 6.0. SAS Inst., Inc., Cary, NC.

Sheehan, J. J., and T. P. Guinee. 2004. Effect of pH and calcium level on the biochemical, textural and functional properties of reducedfat Mozzarella cheese. Int. Dairy J. 14:161-172.

Walstra, P., and R. Jenness. 1984. Dairy Chemistry and Physics. John Wiley \& Sons, New York, NY.

Wang, Y.-C., K. Muthukumarappan, M. M. Ak, and S. Gunasekaran. 1998. A device for evaluating melt/flow characteristics of cheeses. J. Texture Stud. 29:43-55.

Yun, J. J., L. J. Kiely, P. S. Kindstedt, and D. M. Barbano. 1993. Mozzarella cheese: Impact of coagulant type on functional properties. J. Dairy Sci. 76:3657-3663.

Zaikos, W. J., D. W. Mehnert, and G. L. Kerrigan. 1999. Process and formulation for improved texture and melt of reduced-fat cheese product. Kraft Foods Inc., assignee. US Patent 5,876,770.

Zisu, B., and N. P. Shah. 2007. Texture characteristics and pizza bake properties of low-fat Mozzarella cheese as influenced by pre-acidification with citric acid and use of encapsulated and ropy exopolysaccharide producing cultures. Int. Dairy J. 17:985-997. 